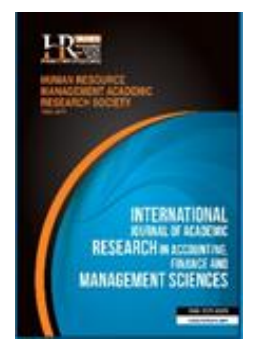

International Journal of Academic Research in Accounting, Finance and Management Sciences

Vol. 10, No.2, April 2020, pp. 244-256

E-ISSN: 2225-8329, P-ISSN: 2308-0337

(C) 2020 HRMARS

www.hrmars.com

To cite this article: Ming, K. L. Y., Jais, M., Wen, C. C., Zaidi, N. S. (2020). Factor Affecting Adoption of E-Wallet in Sarawak, International Journal of Academic Research in Accounting, Finance and Management Sciences 10 (2): 244-256.

http://dx.doi.org/10.6007/IJARAFMS/v10-12/7446

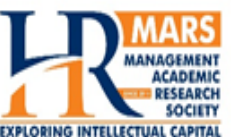

www.hrmars.com

ISSN: $2225-8329$

\title{
Factor Affecting Adoption of E-Wallet in Sarawak
}

\author{
Kelvin Lee Yong Ming, Mohamad Jais, Chan Chia Wen, Nurul Syuhada Zaidi \\ Universiti Malaysia Sarawak, ${ }^{1}$ E-mail: kelvinklym910104@gmail.com, ${ }^{2}$ E-mail: jmohamad@unimas.my
}

\begin{abstract}
E-wallet was an innovative payment instrument that arises under financial technology. E-wallet helps to ease the user's daily life, in which users can make their daily transactions without using the notes or coins. Indirectly, E-wallet also helps to reduce the risk of cash being stolen. Undeniably, E-wallet brings more benefits than disadvantages. The primary aim of this study is to examine the factors affecting the adoption of E-wallet services in Sarawak. The questionnaire, which consisted of 26 questions were distributed to the respondents and successfully collected 450 feedbacks. Firstly, this study applied factor analysis to construct all the variables. Also, Cronbach's a coefficient was computed to determine internal consistency reliabilities. Then, this study used regression analysis to test the relationship between the variables. The results of the regression analysis showed that the users would adopt E-wallet when they perceive that the E-wallet is useful and easy to be used. Meanwhile, the findings of this study also showed that rewards tend to attract users to use E-wallet. Besides that, this study also found that higher perceived risk may act as a barrier to stop users from using E-wallet. These results help the E-wallet service providers to identify the significant factors that influence the user's intention to use E-wallet services. Lastly, this study recommended the E-wallet service providers to take the security systems and rewards into consideration for the enhancement of their payment system.
\end{abstract}

Key words E-wallet, Technology Acceptance Model, Theory of Planned Behaviour, Perceived Risk, Rewards

$\begin{array}{lll}\text { Received: } & 21 \text { Jun } 2020 \quad \text { @ The Authors } 2020 \\ \text { Revised: } & 28 \text { Jul } 2020 \quad \text { Published by Human Resource Management Academic Research Society (www.hrmars.com) }\end{array}$

Accepted: $\quad 08$ Aug 2020 This article is published under the Creative Commons Attribution (CC BY 4.0) license. Anyone may reproduce, distribute, translate and create derivative works of this article (for both commercial and non-commercial purposes), subject to full attribution to the original publication and authors. The full terms of this license may be seen at: http://creativecommons.org/licences/by/4.0/legalcode

\section{Introduction}

FinTech, a short form of financial technology, refers to the innovative sector that incorporates the technology with the finance industry (Ion \& Alexandra, 2016). Financial innovation is needed to reduce costs and risks of the users since the financial industry owns a vital role in facilitating the economic growth (Frame \& White, 2014). In addition, FinTech enhances the transparency and efficiency of the financial process and brings convenience to the users (Zavolokina et al., 2016). FinTech companies also expand their business scope into smartphones as smartphones are the popular tools used by the consumers for banking, payments, budgeting, shopping, or even stock trading. The technology advancement also contributes to the increment in the smartphone users to subscribe for FinTech services (Ryu, 2018).

The emergence of the smartphone completely transforms the way how a person communicates and stay connected with others over the past decade. By connecting to the internet, the smartphone able to perform multiple tasks, such as online shopping, purchasing cinema tickets, sending documents, etc. These features also make the user's life more comfortable and feeling stress-free (Punwatkar \& Verghese, 2018). In the aspect of the business, the seller also utilized the smartphone to change their distribution channel and selling network. Meanwhile, banks also developed several applications or products that fit in the 
smartphone to enhance their competitiveness in this technology era (Yen, 2017). Figure 1 shown that the percentage of smartphone users in Malaysia increase from only 14\% in 2010 to $78 \%$ in 2018. Since the smartphone became an important tool for human beings, and thus payments via smartphones are no longer the strange phenomena in many countries (Liu \& Tai, 2016).

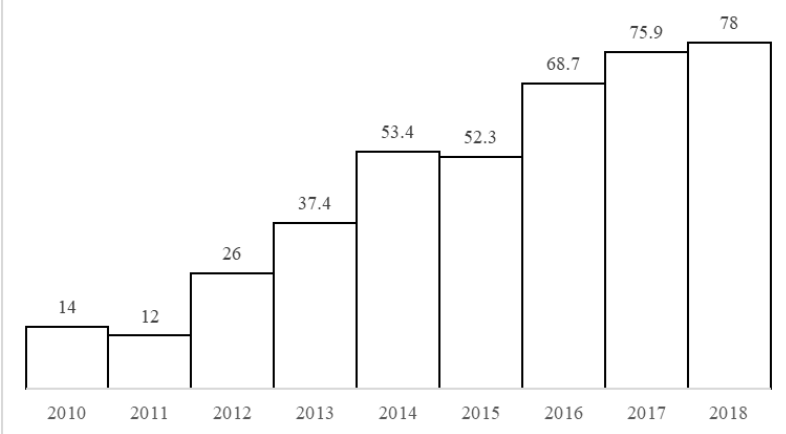

Source: MCMC 2018

Figure 1. Percentage of Smartphone Users from 2010 to 2018

The lifestyle of everyone has changed during this digital era. E-wallet is one of the most innovative financial technology products that emerge in the digital era. E-wallet defined as the electronic payment instruments that enable the users to make transactions anytime anywhere, for instance, using E-wallet apps that installed in their smartphone to purchase items at the convenience store (Punwatkar \& Verghese, 2018). Meanwhile, convenience and speedy transactions are significant factors that attract the customer in using the e-wallet for online shopping purposes (Manikandan \& Jayakodi, 2015). Several key features of Ewallet also mentioned by Varsha and Thulasiram (2016), which include (i) easy to use, (ii) low deposit amount, and (iii) sharing of E-wallet's benefits with the others. As one of the greatest innovations in this era, e-wallet also slowly replaces the usage of cash in the physical form (Dalimunite et al., 2019). However, Subaramaniam et al. (2020) argued out that elders usually need to take a longer period to adapt to the Ewallet services since holding cash will make them feel more secured.

Bank Negara Malaysia (BNM) issued 48 e-wallet licenses to cultivate Malaysian apply the cashless culture in the society before 2050 (Yunus, 2018; Tan, 2019). Various E-wallet services arise in Malaysia, and the related advertisements can be found in the restaurant, shopping mall, or even roadside. Meanwhile, Ewallet service provider also introduced different rewarding schemes to boost up the number of users. Recently, Malaysia was giving out a one-off RM 30 e-Tunai Rakyat incentives to encourage Malaysian to use E-wallet. The total incentives worth RM 450 million also expected to benefit 15 million Malaysian (Azura, 2020). Indirectly, the e-Tunai Rakyat incentives program accelerating the speed of transforming into the digital economy.

Among all the E-wallet available in Malaysia, there were three famous and well-known E-wallet providers who successfully dominate the market after the first half of 2018 until the end of 2019. Table 1 shows the ranking of the E-wallet by the number of active users. Grab Pay consistently dominates the market since the third quarter of 2018 until last quarter of 2019. As of 2020, there were more than 20 million downloads for Grab apps (Hassan, 2020). On the other hand, Touch $n$ Go and Boost had 5 million and 4.8 million users, respectively. Noteworthy, Touch $n$ Go and Boost currently had more than 100,000 merchants participated in their platform (Ker, 2019).

Since the existence of E-wallet, there was an uptrend in both the volume and value of E-wallet transactions in Malaysia (Figures 2 and 3). Figure 2 shows that there was just a total of 365.6 million Ewallet transactions achieved in 2005 and increase dramatically to 1.92 billion in 2018. As of October 2019, there were a total of 1.72 billion E-wallet transactions in Malaysia. In terms of value, the total value of the transaction that had been done through E-wallet achieved the record high of RM 13.9 billion as of October 2019 (Figure 3). In addition, Wiese and Humbani (2019) pointed out that growth in online shopping contributed to the massive usage of the digital wallet. As shown in Figure 4, the contribution of Ecommerce to Malaysia's GDP climbed from RM 89.1 billion in 2015 to RM 115.5 billion in 2018. E-wallet usage is increasing rapidly in Malaysia and it is crucial to understand the reason behind this amazing 
International Journal of Academic Research in Accounting, Finance and Management Sciences Vol. 10 (2), pp. $244-256$, @ 2020 HRMARS (www.hrmars.com)

increment. The findings of this study also expected to help the E-wallet provider to have a better idea in capturing their potential customers.

Table 1. Top E-Wallet in Malaysia

\begin{tabular}{|c|c|c|c|c|c|c|}
\hline \multirow{3}{*}{ Ranking } & \multicolumn{6}{|c|}{ Year } \\
\hline & \multicolumn{2}{|c|}{2018} & \multicolumn{4}{|c|}{2019} \\
\hline & $3^{\text {rd }}$ Quarter & $4^{\text {th }}$ Quarter & $1^{\text {st }}$ Quarter & $2^{\text {nd }}$ Quarter & $3^{\text {rd }}$ Quarter & $4^{\text {th }}$ Quarter \\
\hline $1^{\text {st }}$ & Grab & Grab & Grab & Grab & Grab & Grab \\
\hline $2^{\text {nd }}$ & & $\begin{array}{l}\text { कouch } \\
\text { owallot }\end{array}$ & $\begin{array}{l}\text { Thuch } \\
\text { ewallot }\end{array}$ & $\begin{array}{l}\text { Touch } \\
\text { ewallot } \\
\text { ats }\end{array}$ & $\begin{array}{l}\text { Thuch } \\
\text { swallot }\end{array}$ & $\begin{array}{l}\text { Touch } \\
\text { ewallot }\end{array}$ \\
\hline $3^{\text {th }}$ & & & & & & \\
\hline
\end{tabular}

Source: $\operatorname{Ker}(2019)$

Source: BNM

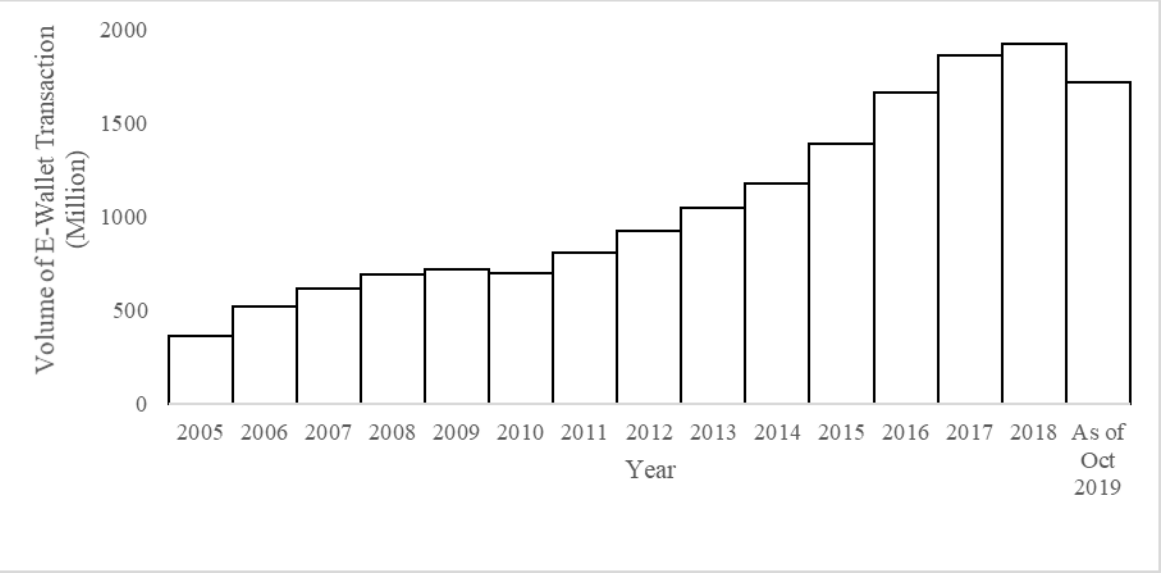

Figure 2. Volume of E-Wallet Transaction (in Million) from 2005 to 2019

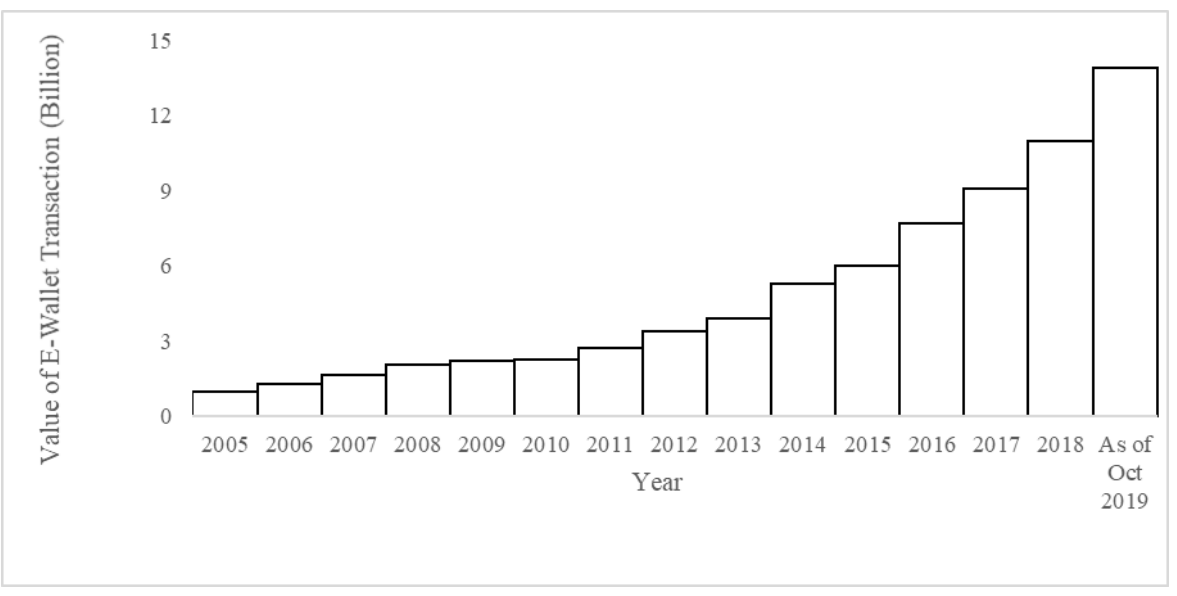

Source: BNM

Figure 3. Value of E-Wallet Transaction (in RM Billion) from 2005 to 2019 


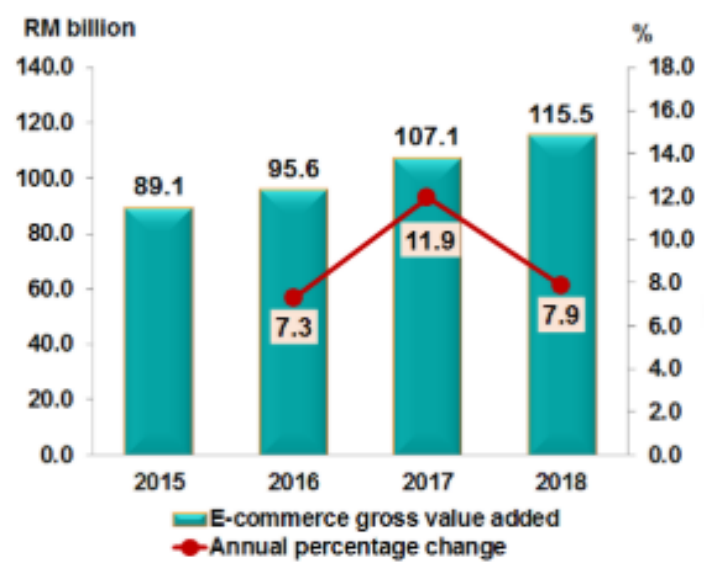

Source: Department of Statistics Malaysia (2018)

Figure 4. E-Commerce Gross Value Added to GDP

\section{Literature review}

This section begins with a discussion of the related theories. Also, this section discussed the existing literature related to the factors that influence the adoption of E-wallet. A considerable amount of studies has been carried out to investigate the factors that affect the user in using E-wallet. Along with that, Technology acceptance model (TAM) developed by Davis (1986) was widely applied in the research field to study the factors that influence the user to use a new technology system. Figure 5 illustrates two primary factors - (i) perceived usefulness (PU) and (ii) perceived ease of use (PEOU) that affects the users' attitude in using a new system. TAM model is constructed based on the Theory of Reasoned Action (TRA) developed by Fishbein and Ajzen (1975). TRA hypothesized that a person's behavioural intention tends to affect their behaviour. Meanwhile, TRA suggests that a person's behavioural intention is determined by his or her attitude and subjective norms. Figure 6 illustrates the relationship between a person's attitude, subjective norms and behavioural.

Thereafter, Ajzen (1985) formed Theory of Planned Behaviour (TPB) by incorporating the perceived behavioural control into TRA. As illustrated in Figure 7, perceived behavioural control was an exogenous variable which posed both the direct and indirect effects on the person's behaviour. Perceived behavioural control is the belief of a person about the available resources or opportunities that facilitate their intentions to perform an intention (Ajzen \& Madden, 1986). Thus, higher level of resources and opportunities tend to lead a person to have a greater perceived behavioural control over their behaviour (Madden et al., 1992). As a summary, TPB predict the interest or intention of consumers to perform a particular action. This study integrates the TPB into TAM model to investigate the potential factors that influence the user in adopting E-wallet in Sarawak.

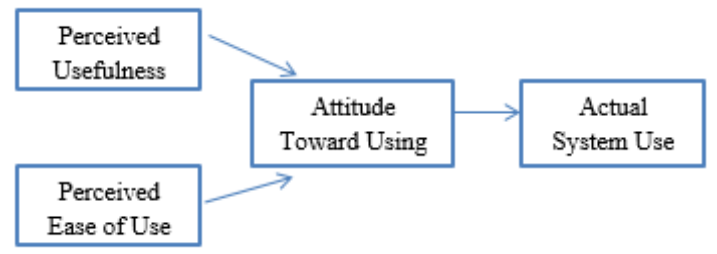

Figure 5. Technology Acceptance Model (TAM)

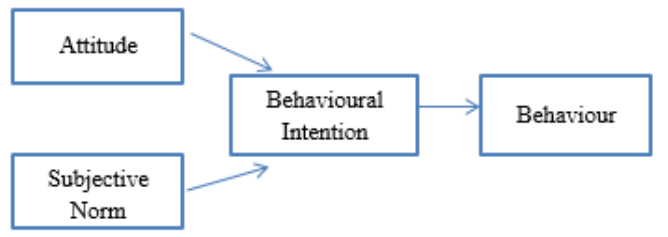

Figure 6. Theory of Reasoned Action (TRA) 


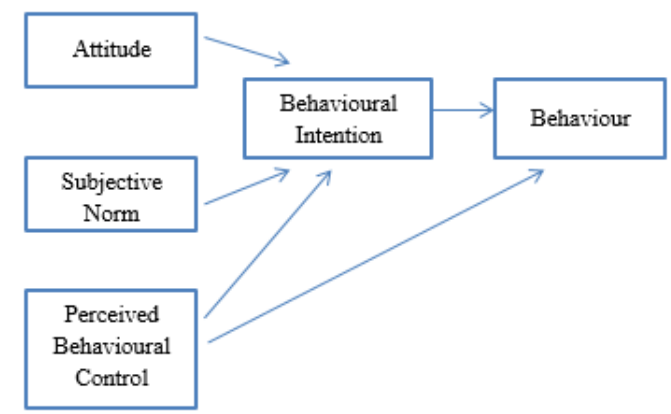

Figure 7. Theory of Planned Behaviour (TPB)

\subsection{Perceived usefulness and perceived ease of use}

Perceived usefulness (PU) refers to the users' perspective that the useful new technology system able to enhance their performance. Meanwhile, perceived ease of use (PEUO) relates to the users' perspective that usage of a system would require less effort in completing their tasks (Davis, 1989). Based on TAM, Liu \& Tai (2016) conducted research in examine the determinants for the intention of E-wallet usage in Vietnam. They revealed that both PU and PEOU profoundly influence the users' intention in using E-wallet. Through the qualitative questionnaire, they realized that compatibility owns significant impact on both the PU and PEOU. However, they found that users' risk perception had no effect on the users' E-wallet usage intention. Lastly, the researcher pointed out there was a need for the E-wallet service provider to understand the factors that stop the elder group from using E-wallet in Vietnam.

On the other hand, Trivedi (2017) using TAM to investigate the factors that influence Generation $Y$ in India to accept E-wallet. He mentioned that $65 \%$ of the Indian population aged under 35 years old. His results provide support to the TAM, in which the PU and PEOU play an essential role in affecting the Indian Gen $Y$ in accepting the E-wallet services in India. Seetharaman et al. (2017) extended the TAM by include eight more variables as the potential factors that affect Singaporean's intentions in using E-wallet. They suggested industry players of E-wallet to enhance transaction security to attract more users. On the other hand, they found that PEOU did not show any significant impact to the users' intention in using E-wallet. However, they discovered that PEOU has demonstrated a strong influence on the PU. Lastly, they also recommend the services provider to enhance the transaction speed in order to increase the PU of the mobile wallet.

Taufan \& Yuwono (2018) examined the factors that affect Indonesian in using the GO-Pay Application. GO-Pay is an electronic payment instrument that widely used by Indonesian. There were more than $79 \%$ of Indonesian make their daily transaction by using GO-Pay. Their results indicate that PU positively related with the usage of GO-Pay, but not PEOU. Another study is carried out by Nag \& Gilitwala (2019) in Bangkok, Thailand to examine the factor in affecting the user's intention to adopt E-wallet. They revealed the PU and PEOU tend to attract more E-wallet users in Thailand.

Recently, Karim et al. (2020) examined the factors that affect Malaysian young adults in adopting the E-wallet. However, this study only focused in the students who pursued university degree in Klang Valley area. Thus, the results of Karim et al. (2020) may not generalize the decision of Malaysian young adults. They also emphasized that the choice of young adults may vary according to their income level. Their results showed that both higher levels of PU and PEOU linked with the higher usage of E-wallet in Malaysia.

By combining TAM with the TPB, Friadi et al. (2015) investigated the factors that influence the attitude and intention of using smartphone-based electronic money in Indonesia. Consistent with the assumption of TAM, they revealed that a higher level of PU and PEOU tend to encourage more Indonesian to use smartphone-based e-money. On the other hand, Gbongli et al. (2019) extend the TAM model by incorporating technology anxiety and personal innovativeness as the potential factors that affect a person in using E-wallet. They also found that PU and PEOU positively related with the intention of adopting Ewallet. However, they pointed out that the effect of PEOU will be more significant than PU. This study proposed the following hypotheses based on the literature reviewed.

H1: Perceived usefulness (PU) positively related with the users' adoption of E-wallet.

H2: Perceived ease of use (PEOU) positively related with the users' adoption of E-wallet. 


\subsection{Perceived risk}

Perceived risk (PR) refers to the thought of possible adverse outcomes or consequences that shall be aroused from the usage of a particular service (Featherman \& Pavlou, 2003). Earlier study of Mitchell (1999) also emphasized that users' risk perception strongly influences the intention of the users in using digital payment. Furthermore, users would always focus in minimizing the risk, but not maximizing the utility of the digital payment mechanism (Bauer et al., 2005). On the other hand, Kim et al. (2008) mentioned that PR own substantial impacts in influencing the consumers' intention in online purchasing. A later study of Lee (2009) also revealed that higher perceived risk tends to reduce users' interest in adopting internet banking.

In the context of Malaysia, Hamid \& Cheng (2013) investigated the risk perception and behaviour of young adults towards various payment methods in Malaysia. They found that Malaysian young adult perceives the transaction by cash will be safer than E-payment. However, they argued that perception of the young adult will be varying according to the transaction amount. Besides that, Lai \& Zainal (2015) extended the TAM model by incorporating the perceived risk in their study. They found that perceived risk tend to lower down the consumers' intention in using E payment system. However, their study only limited to the internet users. Similarly, Yang et al. (2015) examine the impacts of the various dimensions of PR towards the consumers' intention in using mobile wallet. Consistent with the findings of Lai \& Zainal (2015), Yang et al. (2015) revealed that PR tends to affect the consumers' intention negatively. Specifically, Yang et al. (2015) found that perceived performance risk, financial risk and privacy risk adversely affect the consumers' acceptance of mobile payment mechanisms.

A recent study conducted by Wong \& Mo (2019) revealed that the users from Hong Kong do not have a good perception towards the security of mobile payment. Throughout the analysis, they also revealed that PR had a negative effect on the consumers' intention to use mobile payment. They also recommend that mobile payment provider should enhance the security system by changing the password protection to facial recognition or fingerprint. On the other hand, Alaeddin et al. (2019) revealed that PR had an indirect impact towards the intention of using a digital wallet, in which the attitude of consumer acts as a mediating variable. By incorporating the innovativeness resistance theory in the model, Aransyah et al. (2019) revealed that a high level of PR would pose a negative impact towards the usage of E-wallet. They also argued that the risk of losing the E-wallet is similar to cash because the user cannot claim back whatever is being stolen. Furthermore, Ahmed \& Sajid (2019) mentioned that users also worried about information leakage when they are using E-wallet. In addition, Subaramaniam et al. (2020) who reported that most of the respondents stated that security risk is the primary concern for them in using E-wallet. This study proposed the following hypotheses based on the literature reviewed.

\section{H 3: Perceived risk (PR) negatively related with the users' adoption of E-wallet.}

\subsection{Rewards}

The term 'rewards' refers to the benefits that could be obtained from the seller right after their spending. As pointed by Dmeoulin \& Zidda (2009), retailers usually provide monetary advantage and psychological advantage to retain their customers' loyalty. In addition, the reward may come in different forms, which included monetary incentives, free gift, and coupons (Aydin \& Burnaz, 2016). Recently, Singh et al. (2020) mentioned that users only adopt the E-wallet services when the E-wallet provide benefit, such as cashback or reward point to the users. For instances, Singh et al. (2020) reported that mobile transaction rose by $38 \%$ from 235.5 million in 2017 to 325.2 million in 2018 as a result of several incentives has been given or offered to the users. The incentives include the waiver in service taxes and cash backs. In Malaysia, Subaramaniam et al. (2020) reported that $22 \%$ of the respondents agreed that E-wallet brought rewards. They also pointed out some examples, such as some shopping malls or restaurants working closely with the E-wallet service provider to offer attractive rewards or benefits to the customers. This study proposed the following hypotheses based on the literature reviewed.

$H$ 4: Reward (RW) positively related with the users' adoption of E-wallet. 


\section{Methodology of research}

This section discusses the data collection process and research methodologies applied in this study. Purposive sampling method was used to select the respondent for this study since this study only intends to collect the feedbacks from Sarawakian during the period between June 2019 and February 2020. This study used the application of Google form to create the intangible questionnaire. Then, intangible questionnaires were sent to the respondents and successfully collected feedbacks from 450 respondents. The questionnaire consists of 2 sections, in which Section A gathers information related to the respondent's background and Section B collects feedbacks for 18 statements from the respondents. Specifically, respondents need to express their extent of agreement to the total of 18 statements based on the sevenpoint Likert scale ( 1 = "strongly disagree" and $7=$ "strongly agree").

After collecting the data, the respondent's demographic information was summarized in the next section. Then, the factor loading for each item and Cronbach's $\alpha$ coefficient were calculated. Notably, Cronbach's $\alpha$ coefficient of exceeding 0.8 is preferable. Then, this study applied the regression analysis to investigate the relationship between the variables. The dependent variable used in this study was the adoption of the E-wallet, whereas the independent variables used in this study were (i) perceived usefulness, (ii) perceived ease of use, (iii) perceived risk and (iv) rewards. In accordance with the theoretical basis and literature reviewed, the hypotheses are summarized in Figure 8.

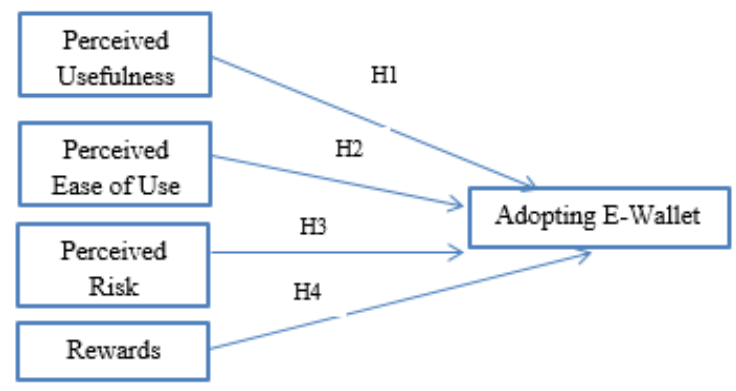

Figure 8. Conceptual Framework of the Study

\section{Results and discussions}

This section discusses the results obtained in this study. Firstly, descriptive statistics is used to summarize the respondent's demographic information.

The descriptive statistics of demographic information are presented in Table 2 . The majority of the respondents were female $(52.44 \%)$ and single $(67.11 \%)$. Besides that, about $30.22 \%$ of the respondents come from the group of 21 to 25 years old, followed by the group of below 21 years old $(21.11 \%)$ and $26-30$ years old (16.89\%). From the aspect of education, most of the respondents (30\%) were Degree graduates, followed by SPM leavers (27.11\%) and Diploma holder (26.89\%). Nearly half of the respondents (47.11\%) were employees and $65.56 \%$ of them earning more than RM 1,000 per month. Besides that, a large proportion of respondents (71.56\%) also used E-wallet for less than a year and $46.22 \%$ of them had an experience of using E-wallet before. In the other word, $46.22 \%$ of the respondents were using more than one E-wallet. 
Table 2. Demographic Information of the Respondents

\begin{tabular}{|c|c|c|c|}
\hline \multicolumn{4}{|c|}{ Total Respondents: 450} \\
\hline & & Frequency & Percentage \\
\hline \multirow{2}{*}{ Gender } & Male & 214 & $47.56 \%$ \\
\hline & Female & 236 & $52.44 \%$ \\
\hline \multirow[t]{2}{*}{ Marital Status } & Married & 148 & $32.89 \%$ \\
\hline & Single & 302 & $67.11 \%$ \\
\hline \multirow[t]{6}{*}{ Age (Years Old) } & $<21$ & 95 & $21.11 \%$ \\
\hline & 21 to 25 & 136 & $30.22 \%$ \\
\hline & 26 to 30 & 76 & $16.89 \%$ \\
\hline & 31 to 35 & 49 & $10.89 \%$ \\
\hline & 36 to 40 & 23 & $5.11 \%$ \\
\hline & $>40$ & 71 & $15.78 \%$ \\
\hline \multirow[t]{6}{*}{ Education Level } & Penilaian Menengah Rendah & 7 & $1.56 \%$ \\
\hline & Sijil Pelajaran Malaysia & 122 & $27.11 \%$ \\
\hline & Sijil Tinggi Persekolahan Malaysia & 43 & $9.56 \%$ \\
\hline & Diploma & 121 & $26.89 \%$ \\
\hline & Bachelor's Degree & 128 & $28.40 \%$ \\
\hline & Master's Degree & 29 & $6.44 \%$ \\
\hline \multirow[t]{5}{*}{ Occupation } & Student & 139 & $30.89 \%$ \\
\hline & Self-employed & 59 & $13.11 \%$ \\
\hline & Employee & 212 & $47.11 \%$ \\
\hline & Housewife & 17 & $3.78 \%$ \\
\hline & Others & 23 & $5.11 \%$ \\
\hline \multirow[t]{5}{*}{ Income (RM) } & $<1,000$ & 155 & $34.44 \%$ \\
\hline & 1,000 to 2,000 & 116 & $25.78 \%$ \\
\hline & 2,001 to 3,000 & 80 & $17.78 \%$ \\
\hline & 3,001 to 4,000 & 34 & $7.56 \%$ \\
\hline & $>4,000$ & 65 & $14.44 \%$ \\
\hline \multirow[t]{2}{*}{ E-wallet experience } & Yes & 208 & $46.22 \%$ \\
\hline & No & 242 & $53.78 \%$ \\
\hline \multirow[t]{3}{*}{ Using E-wallet for } & Under 1 year & 322 & $71.56 \%$ \\
\hline & 1 to 2 years & 85 & $18.89 \%$ \\
\hline & 2 years and above & 43 & $9.56 \%$ \\
\hline
\end{tabular}

Table 3 breakdown the demographic information of respondents based on the different periods for E-wallet usage. Based on Table 3, the majority of the respondent has been using E-wallet for less than one year, in which 175 of the respondents were below 25 years old. In the aspect of age, Table 3 clearly showed that $86.32 \%$ of the respondents from the age group of below 21 have started to use E-wallet for a year or a few months ago. Surprisingly, the results also shown than $78.87 \%$ of the respondents from the age group have begun to use E-wallet recently. On the other hand, $35.94 \%$ of the Degree holders and $50 \%$ of the Master Degree holders used E-wallet for more than 1 year. In the aspect of occupation, $88.23 \%$ of the housewife has been using E-wallet for more than 1 year, whereas $83.45 \%$ of the students used the E-wallet for less than a year. The last row of Table 3 showed that nearly half of the respondents with income more than RM 3,000 have been using E-wallet for more than 1 year. 
Table 3. Period of E-Wallet Usage Based on Demographic Information

\begin{tabular}{|c|c|c|c|c|}
\hline & & \multicolumn{3}{|c|}{ Usage of E-wallet } \\
\hline & & Less than a year & 1 to 2 year & More than 2 years \\
\hline \multirow{6}{*}{$\begin{array}{l}\text { Age } \\
\text { (Years Old) }\end{array}$} & $<21$ & $82(86.32 \%)$ & $9(9.47 \%)$ & $4(4.21 \%)$ \\
\hline & 21 to 25 & $93(68.4 \%)$ & $33(24.26 \%)$ & $10(7.35 \%)$ \\
\hline & 26 to 30 & $47(61.84 \%)$ & $19(25.00 \%)$ & $10(13.16 \%)$ \\
\hline & 31 to 35 & $32(65.31 \%)$ & $11(22.45 \%)$ & $6(12.24 \%)$ \\
\hline & 36 to 40 & $12(52.17 \%)$ & $8(34.78 \%)$ & $3(13.04 \%)$ \\
\hline & $>40$ & $56(78.87 \%)$ & $5(7.04 \%)$ & $10(14.08 \%)$ \\
\hline \multirow{6}{*}{$\begin{array}{l}\text { Education } \\
\text { Level }\end{array}$} & Penilaian Menengah Rendah & $6(85.71 \%)$ & $0(0.00 \%)$ & $1(14.29 \%)$ \\
\hline & Sijil Pelajaran Malaysia & $99(81.15 \%$ & $17(13.93)$ & $6(4.92 \%)$ \\
\hline & Sijil Tinggi Persekolahan Malaysia & $33(76.74 \%)$ & $3(6.98 \%)$ & $7(16.28 \%)$ \\
\hline & Diploma & $87(71.90 \%)$ & $23(19.00 \%)$ & $11(9.09 \%)$ \\
\hline & Bachelor's Degree & $82(64.06 \%)$ & $33(25.78 \%)$ & $13(10.16 \%)$ \\
\hline & Master's Degree & $10(34.48 \%)$ & $13(44.83 \%)$ & $6(20.69 \%)$ \\
\hline \multirow[t]{5}{*}{ Occupation } & Student & $116(83.45 \%)$ & 19 (13.67\%) & $4(2.88 \%)$ \\
\hline & Self-employed & 34 (57.62\%) & 10 (16.95\%) & $15(25.42 \%)$ \\
\hline & Employee & $138(65.09 \%)$ & $52(24.53 \%)$ & $22(10.38 \%)$ \\
\hline & Housewife & $2(11.76 \%)$ & $13(76.47 \%)$ & $2(11.76 \%)$ \\
\hline & Others & $18(78.26 \%)$ & 4 (17.39\%) & $1(4.35 \%)$ \\
\hline \multirow[t]{5}{*}{ Income (RM) } & $<1,000$ & 135 (87.10\%) & $16(10.32 \%)$ & $4(2.58 \%)$ \\
\hline & 1,000 to 2,000 & $82(70.69 \%)$ & $25(21.55 \%)$ & $9(7.76 \%)$ \\
\hline & 2,001 to 3,000 & $59(73.75 \%)$ & $13(16.25 \%)$ & $8(10.00 \%)$ \\
\hline & 3,001 to 4,000 & $18(52.94 \%)$ & $13(38.24 \%)$ & $3(8.82 \%)$ \\
\hline & $>4,000$ & 34 (52.31\%) & $13(20.00 \%)$ & 18 (27.69\%) \\
\hline
\end{tabular}

Notes: The percentage in the brackets is calculated based on the number of respondents in that particular group. For instance, 82 respondents are representing $86.32 \%$ of the group less than 21 years old. Calculation: [82 / $(82+9+4)] x$ $100 \%=86.32 \%$.

All the respondents are required to response to the statements in the questionnaire, in which the scale of 1 representing "strongly disagree" and the scale of 7 representing "strongly agree". Table 4 is shown the summary statistics for the responses collected. On average, the respondent has shown a higher agreement to the statements related to PU and PEOU, followed by PR and RW. As reported in Table 4, the average scale for all the items ranged from 4.198 to 4.878 . Table 4 also reported the value of Cronbach's $\alpha$ for the variables. According to Khairul et al. (2018), a Cronbach's $\alpha$ coefficient value that ranged between 0.6 and 0.8 is considered as moderate and acceptable. In addition, Khairul et al. (2018) mentioned Cronbach's $\alpha$ coefficient value that exceeds 0.80 indicates that the particular set of items is reliable. The value of Cronbach's $\alpha$ obtained for the variables ranging from 0.864 to 0.944 . This indicated that the measurements for the variables are reliable in this study. 
Table 4. Results of Factor Analysis and Cronbach Alpha

\begin{tabular}{|c|c|c|c|c|c|}
\hline Variables & Item & Mean & Standard deviation & Factor Loadings & $\alpha$ \\
\hline \multirow{3}{*}{ PU } & PU 1 & 4.878 & 1.560 & 0.878 & \multirow{3}{*}{0.944} \\
\hline & PU 2 & 4.862 & 1.556 & 0.934 & \\
\hline & PU 3 & 4.804 & 1.508 & 0.919 & \\
\hline \multirow{5}{*}{ PEOU } & PEOU 1 & 4.853 & 2.045 & 0.649 & \multirow{5}{*}{0.910} \\
\hline & PEOU 2 & 4.700 & 1.543 & 0.901 & \\
\hline & PEOU 3 & 4.636 & 1.515 & 0.876 & \\
\hline & PEOU 4 & 4.602 & 1.510 & 0.849 & \\
\hline & PEOU 5 & 4.827 & 1.535 & 0.885 & \\
\hline \multirow{4}{*}{ PR } & PR 1 & 4.442 & 1.706 & 0.745 & \multirow{4}{*}{0.864} \\
\hline & PR 2 & 4.487 & 1.473 & 0.780 & \\
\hline & PR 3 & 4.420 & 1.578 & 0.804 & \\
\hline & PR 4 & 4.122 & 1.497 & 0.757 & \\
\hline \multirow{3}{*}{ RW } & RW 1 & 4.198 & 1.661 & 0.836 & \multirow{3}{*}{0.908} \\
\hline & RW 2 & 4.220 & 1.700 & 0.870 & \\
\hline & RW 3 & 4.238 & 1.664 & 0.864 & \\
\hline \multirow{3}{*}{$\begin{array}{l}\text { Adoption of } \\
\text { E-Wallet (AD) }\end{array}$} & AD 1 & 4.618 & 1.591 & 0.903 & \multirow{3}{*}{0.942} \\
\hline & AD 2 & 4.547 & 1.573 & 0.899 & \\
\hline & AD 3 & 4.607 & 1.599 & 0.914 & \\
\hline
\end{tabular}

Table 5 reported the results of correlation analysis for the variables. All the correlation among the variables was significant at $5 \%$ level of significance. AD is positively correlated with PU, PEOU and RW, whereas $A D$ is negatively correlated with PR. Specifically, PEOU showed the strongest positive correlation (0.756) with the AD, followed by PU (0.744) and RW (0.641). Although PR negatively correlated with AD, the association is the weakest with a coefficient of only -0.343 .

Table 5. Results of Correlation Analysis

\begin{tabular}{|l|l|l|l|l|l|}
\hline Variable & AD & PU & PEOU & PR & RW \\
\hline AD & 1.000 & 0.744 & 0.756 & -0.343 & 0.641 \\
\hline PU & 0.744 & 1.000 & 0.856 & -0.185 & 0.499 \\
\hline PEOU & 0.756 & 0.856 & 1.000 & -0.287 & 0.561 \\
\hline PR & -0.343 & -0.185 & -0.287 & 1.000 & -0.334 \\
\hline RW & 0.641 & 0.499 & 0.561 & -0.334 & 1.000 \\
\hline
\end{tabular}

Table 6 presented the results of regression analysis. At the significance level of $1 \%$, the results shown that four independent variables significantly related with the adoption of E-wallet in Sarawak. In addition, the signs of independent variables were similar to the results of correlation analysis. The R-square of 0.6819 indicates that $68.19 \%$ of the variation in dependent variable was explained by the independent variables. Three independent variables, which included PU, PEOU and RW shown a significant and positive relationship with the adoption of E-wallet in Sarawak. The results reported were also consistent with the assumption of TAM, in which both the PU and PEOU posed a significant impact to the adoption of the new technology system. Based on the results obtained, higher rewards tend to attract users in using the E-wallet services. Consistent with Aransyah et al. (2019), the results also shown that PR negatively related with the adoption of $\mathrm{W}$-wallet. These results also implied that the user would not choose E-wallet as the payment method when the PR is high.

Table 6. Results of Regression Analysis

\begin{tabular}{|c|c|c|}
\hline \multicolumn{3}{|c|}{$\begin{array}{l}\text { Dependent variable }=\text { Adoption of E-Wallet } \\
\text { R-squared }=0.6819\end{array}$} \\
\hline Independent Variable & Coefficient & p-value \\
\hline $\mathrm{PU}$ & 0.378 & $0.000 * * *$ \\
\hline PEOU & 0.257 & $0.000 * * *$ \\
\hline$P R$ & -0.113 & $0.000 * * *$ \\
\hline RW & 0.281 & $0.000 * * *$ \\
\hline
\end{tabular}


Table 7 summarized the results of hypothesis testing in this study. Based on the results obtained, four of the hypothesis tested in this study was supported. Consistent with the results of several researchers (Friadi et al., 2015; Gbongli et al., 2019; Karim et al., 2020; Liu \& Tai, 2016; Nag \& Gilitwala, 2019; Trivedi, 2017), PU and PEOU found to be positively related with the users' adoption of E-wallet. Meanwhile, consistent with the findings of several researchers (Aransyah et al., 2019; Lai \& Zainal, 2015; Wong \& Mo, 2019; Yang et al., 2015), the findings of this study also showed that higher PR tends to lower down the user's adoption of E-wallet. Lastly, this study also revealed that RW tend to attract the user to adopt Ewallet. This result is also consistent with the most recent study of Singh et al. (2020) who mentioned that benefit or rewards tend to encourage users to adopt E-wallet services.

Table 7. Results of Hypothesis Testing

\begin{tabular}{|c|cl|c|}
\hline Factors & \multicolumn{2}{|c|}{ Hypothesis } & Results \\
\hline PU & $\mathrm{H}_{1}:$ & PU positively related with the users' adoption of E-wallet. & Supported \\
\hline PE & $\mathrm{H}_{2}:$ & PEOU positively related with the users' adoption of E-wallet. & Supported \\
\hline PR & $\mathrm{H}_{3}:$ & PR negatively related with the users' adoption of E-wallet. & Supported \\
\hline $\mathrm{RW}$ & $\mathrm{H}_{4}:$ & RW positively related with the users' adoption of E-wallet. & Supported \\
\hline
\end{tabular}

\section{Conclusions}

E-wallet was the most exceptional financial innovations product. The emergence of E-wallet also serves as an impetus for the country to move towards the target of a cashless society. Hence, the principal aim of this study was to investigate the significant factors that affect the user in adopting E-wallet services in Sarawak, Malaysia. This study found that the majority of the respondents only used the E-wallet for less than a year. In addition, the empirical results also indicated that a higher level of perceived usefulness and perceived ease tend to attract more users in adopting E-wallet services. However, the empirical results also suggest that users will refuse to use E-wallet when they think that perceived risk is high. Interestingly, this study also found that rewards had a significant positive impact on the adoption of E-wallet service. This study also confirms the previous findings and contributes additional evidence that may benefit the E-wallet service providers. Specifically, the E-wallet service providers are suggested to focus on two factors, which were risk controlling and rewards. Lastly, this study also recommends E-wallet service providers to organize more campaigns to educate the public regarding the benefits of E-wallet.

\section{Acknowledgement}

Financial support from University Malaysia Sarawak and Digital Sarawak CoE [UHSB/B-AM2018/083] are gratefully acknowledged. All remaining flaws are the responsibilities of the authors.

\section{References}

1. Ahmed, M. S., \& Sajid, S. A. (2019). E-Wallet Awareness and Its Benefit among the People with Special Reference to Vellore District of Tamil Nadu - India. Vidyabharati International Interdisciplinary Research Journal 9(2): 25-31.

2. Ajzen, I. (1985). Attitudes, Personality and Behavior. USA: Open University Press

3. Ajzen, I., \& Madden, T. J. (1986). Prediction of Goal-Directed Behavior: Attitudes, Intentions and Perceived Behavioral Control. Journal of Experimental Social Psychology 22(5): 453-474.

4. Alaeddin, O., Rana, A., Zainuddin, Z., \& Kamarudin, F. (2018). From Physical to Digital: Investigating Consumer Behaviour of Switching to Mobile Wallet. Polish Journal of Management Studies 17(2): $18-30$

5. Aransyah, M. F., Roy, J., \& Aprianti, Y. (2019). Innovation Resistance and Perceive Novelty on EWallet Services. Paper presented at the $2^{\text {nd }}$ Mulawarman International Conference on Economics and Business, 5-6 November, Samarinda, East Kalimantan, Indonesia.

6. Ibrahim, M. H., \& Said, R. (2011). Disaggregated consumer prices and oil prices pass-through: evidence from Malaysia. Proceedings of the VI Malaysian National Economics Conference: Vol. 1, edited by Mansor Jusoh, Nor Aini Idris, Tamat Sarmidi, Mohd. Adib Ismail \& Ahmad Mohd Yusof, 5-7 June. Malacca, Malaysia, 296-305. Che 
7. Aydin, G., \& Burnaz, S. (2016). Adoption of Mobile Payment Systems: A Study on Mobile Wallets. Journal of Business Economics and Finance 5(1): 73-92.

8. Bauer, H. H., Barnes, S. J., Reichardt, T., \& Neumann, M. M. (2005). Driving Consumer Acceptance of Mobile Marketing: A Theoretical Framework and Empirical Study. Journal of Electronic Commerce Research 6(3): 181-192.

9. Dalimunte, I., Miraja, B. A., Persada, S. P., \& Prasetyo, Y. (2019). Comparing Generation Z's Behavior Intention in Using Digital Wallet for Online and In-Store Transaction: A Unified Theory of Acceptance and Use of Technology 2 Approach. Journal of Applied Economic Studies 3(65): 660-672.

10. Davis, F. D. (1989). Perceived Usefulness, Perceived Ease of Use, and User Acceptance of Information Technology. MIS Quarterly 13(3): 319-340.

11. Demoulin, N. T. M., \& Zidda, P. (2009). Drivers of Customers' Adoption and Adoption Timing of a New Loyalty Card in the Grocery Retail Market. Journal of Retailing 85(3): 391-405.

12. Featherman, M. S., \& Pavlou, P. A. (2003). Predicting e-services adoption: a perceived risk facets perspective. International Journal of Human-Computer Science 59: 451-474.

13. Fishbein, M. A., \& Ajzen, I. (1992). Belief, Attitude, Intention and Behaviour: An Introduction to Theory and Research. Canda: Addison-Wesley Publishing Company

14. Frame, W. S., \& White, L. J. (2014). Technological Changes, Financial Innovation, and Diffusion in Banking.https://www.nst.com.my/news/government-public-policy/2020/01/556304/e-tunai-rakyatapplication-period-starts-jan-15-free (assessed 20 February 2020).

15. Friadi, H., Sumarwan, U. \& Kirbrandoko (2013). Integration of Technology Acceptance Model and Theory of Planned Behaviour of Intention to Use Electronic Money. International Journal of Science and Research 7(2): 711-716.

16. Gbongli, K., Xu, Y., \& Amedjonekou, M. K. (2019). Extended Technology Acceptance Model to Predict Mobile-Based Money Acceptance and Sustainability: A Multi-Analytical Structural Equation Modelling and Neural Network Approach. Sustainability 11: 1-33.

17. Hamid, N. R. A., \& Cheng, A. Y. (2013). A Risk Perception Analysis on the use of Electronic Payment Systems by Young Adult. WSEAS Transactions on Information Science and Applications 1(10): 2635.

18. Hassan, H. (2020). Malaysia Targets Half Its Population in E-Wallet Push. https://world-newsmonitor.com/money/finance/2020/01/28/malaysia-targets-half-its-population-in-e-wallet-push/ (assessed 20 February 2020).

19. Ion, M., \& Alexandra, M. (2016). Financial Technology (Fintech) and Its Implementation on the Romanian Non-Banking Capital Market. SEA - Practical Application of Science 4(2): 379-384.

20. Karim, M. W., Haque, A., Ulfy, M. A., Hossain, M. A., \& Anis, M. Z. (2020). Factors Influencing the Use of E-Wallet as a Payment Method among Malaysia Young Adults. Journal of International Business and Management 3(2): 1-12.

21. Ker, N. (2019). These are the Top $5 \mathrm{E}-$ Wallets in Malaysia in 2019. https://www.soyacincau.com/ 2019/10/31/ewallet-malaysia-best-grab-boost-touch-n-go-fave-maybank-bigpay-alipay-vcash/ (assessed 20 February 2020).

22. Khairul, A. M. D., Khidzir, N. Z., Ismail, A. R., \& Abdullah, F. A. (2018). Validity and Reliability of Instrument to Measure Social Media Skills among Small and Medium Entrepreneurs at Pengkalan Datu River. International Journal of Development and Sustainability 7(3): 1026-1037.

23. Kim, D. J., \& Ferrin, D. L. (2008). A Trust Based Consumer Decision-Making Model in Electronic Commerce: The Role of Trust, Perceived Risk, and Their Antecedents. Decision Support System 44(2): 1-29.

24. Lai, P. C. (2015). Perceived Risk as Extension to TAM Model: Consumers' Intention to Use a Single Platform E-Payment. Australian Journal of Basic and Applied Sciences 9(2): 323-331.

25. Lee, M. C. (2009). Factors Influencing the Adoption of Internet Banking: An Integration of TAM and TPB with Perceived Risk and Perceived Benefit. Electronic Commerce Research and Applications 8(3): 130-141.

26. Liu, G. S., \& Tai, M. (2016). A Study of Factors Affecting the Intention to Use Mobile Payment Services in Vietnam. Economics World 4(6): 249-273. 
27. Madden, T. J., Ellen, P. S., \& Ajzen, I. (1992). A Comparison of the Theory of Planned Behavior and the Theory of Reasoned Action. Personality and Social Psychology Bulletin 18(1): 3-9.

28. Manikandan, S., \& Jayakodi, M. (2017). An Empirical Study on Consumer Adoption of Mobile Wallet with Special Reference to Chennai City. International Journal of Research - Granthaalayah 5(5): 107115.

29. Nag, A. K., \& Gilitwala, B. (2019). E-Wallet-Factors Affecting Its Intention to Use. International Journal of Recent Technology and Engineering 8(4): 3411-3415.

30. Punwatkar, S., \& Verghese, M. (2018). Adoption of E-Wallet Payment: An Empirical Study on Consumers' Adoption Behavior in Central India. International Journal of Advanced in Management, Technology and Engineering Sciences 8(3): 1147-1156.

31. Ryu, H.S. (2018). What Makes Users Willing or Hesitant to Use Fintech? The Moderating Effect of User Type. https://doi.org/10.1108/IMDS-07-2017-0325 (assessed 19 February 2020).

32. Seetharaman, A., Kumar, K. N., Palaniappan, S., \& Weber, G. (2017). Factors Influencing Behavioural Intention to Use the Mobile Wallet in Singapore. Journal of Applied Economics and Business Research 7(2): 116-136.

33. Singh, N., Sinha, N., \& Liebana-Cabanillas, F. J. (2020). Determining Factors in the Adoption and Recommendation of Mobile Wallet Services in India: Analysis of the effect of innovativeness, stress to use and social influence. International Journal of Information Management 50: 191-205.

34. Subaramaniam, K., Kolandaisamy, R., Jalil, A., \& Kolandaisamy, I. (2020). The Impact of E-Wallets for Current Generation. Journal of Advance Research in Dynamical and Control Systems 12(1): 751-759.

35. Tan, R. (2019). Leaders in e-wallet emerge. https://www.thestar.com.my/business/businessnews/2019/12/02/leaders-in-e-wallet-emerge (assessed 18 February 2020)

36. Taufan, A., \& Yuwono, R. T. (2019). Analysis of Factors That Affect Intention to Use E-Wallet Through the Technology Acceptance Model Approach (Case Study: GO-PAY). International Journal of Science and Research 8(7), 413-419.

37. Trivedi, J. (2016). Factors Determining the Acceptance of E-Wallets. International Journal of Applied Marketing and Management 1(2): 42-53.

38. Varsha, R., \& Thulasiram, M. (2016). Acceptance of E-Wallet Services: A Study of Consumer Behavior. International Journal of Innovative Research in Management Studies 1(4): 133-141.

39. Wiese, M., \& Humbani, M. (2019). Exploring Technology Readiness for Mobile Payment App User. The International Review of Retail, Distribution and Consumer Research 30: 123-142.

40. Wong, W. H., \& Mo, W. Y. (2019). A Study of Consumer Intention of Mobile Payment in Hong Kong, based on Perceived Risk, Perceived Trust, Perceived Security and Perceived Trust, Perceived Security and Technological Acceptance Model. Journal of Advanced Management Sciences 7(2): 33-38.

41. Yang, Y. Q., Liu, Y., Li, H. X., \& Yu, B. (2015). Understanding Perceived Risks in Mobile Payment Acceptance. Industrial Management and Data System 115(2): 253-269.

42. Yen, N. D. H. (2017). Factors Influencing Mobile Banking Adoption in Ho Chi Minh City Based on The Technology Acceptance Model. Paper presented at International Conference for Young Researchers in Economics and Business, ICYREB 2017, 30 October, Da Nang, Vietnam.

43. Yunus, R. (2018). E-wallet platforms to create 'tsunami' of cashless payment this year. http://themalaysianreserve.com/2018/01/23/e-wallet-platforms-createtsunami-cashless-payment-year/ (assessed 18 February 2020)

44. Zavolokina, L., Dolata, M., \& Schwabe, G. (2016). FinTech - What's in a Name? Paper presented at Thirty Seventh International Conference on Information Systems, 11-14 December 2016, Dublin, Ireland. 